Dept. of Physiology,

College of Veterinary Science, University of Baher Ghazal, Sudan

\title{
EFFECT OF DIFFERENT HCI TREATMENTS ON RUMINAL DEGRADATION CHARACTERISTICS OF GROUND NUT CAKE
}

(With 4 Tables)

\author{
By \\ NIDAA. A.M.; S.A. OMER* and M.T. IBRAHIM* \\ * College of Veterinary Medicine and Animal Production, \\ Sudan University of Science and Technology (SUST) \\ (Received at 16/9/2008)

\section{SUMMARY}

The study was conducted to determine the effect of acid $(\mathrm{HCl})$ treatment on ruminal degradation characteristics of dry matter (DM), crude protein (CP), and effective degradability of groundnut cake (GNC). GNC was either soaked in or sprayed with $0.5 \mathrm{~N} \mathrm{HCl}$.The treated cake was either air or oven dried at $\left(100^{\circ} \mathrm{c}\right)$. Nylon bags technique was employed using three castrated calves. $\mathrm{HCl}$ treatment significantly $(\mathrm{P}<0.05)$ decreased in situ dry matter degradation rate. GNC air dried represented the lowest $\mathrm{P}<0.05 \mathrm{CP}$ degradation at all incubation periods except at time interval 36hrs. GNC sprayed had the highest CP degradability at all the incubation periods. Combining heat with $\mathrm{HCl}$ was the most effective treatment in protecting GNC from rumen degradation, while spraying resulted in the least protection.

Key words: Groundnut cake/by-pass protein/Insitu DM, CP degradation.

\section{INTRODUCTION}

Ground nut cake (GNC) is the most commonly used protein supplement in the Sudan for both dairy and beef cattle. It is quite palatable and available. GNC contains large amounts of rumen degradable proteins NRC (2001). Lactating dairy cows and rapidly growing ruminants cannot meet their protein requirements with sole microbial protein. So by- pass proteins are important for these animals. Therefor protecting high quality protein sources from ruminal fermentation affects animal performance positively. 
Various methods for treating proteins have been used to reduce their degradation in the rumen. These methods are most commonly used in Soya been meal (SBM) in the U.S.A feed industry. The methods can be categorized into chemical and physical treatments. Research on chemical methods has concentrated on treatment of SBM with formaldehyde (Spears et al, 1980), alcohol (Vander Aar et al, 1982) and sodium hydroxide, propionic acid and hydrochloric acid (Waltz and Loerch, 1986). In the Sudan, limited data exist in the literature, concerning by-pass proteins.

The objective of this study is to evaluate the effectiveness of acid treatment, applied in different forms, in protecting GNC from microbial degradation in the rumen.

\section{MATERIALS and METHODS}

Groundnut seeds were the crop of the year (2006), from Kordofan State west of the Sudan. The cake was obtained by mechanical extraction of the oil at an oil mill in Omdurman.

\section{Treatment of the cake:-}

One $\mathrm{kg}$ of groundnut cake (GNC) was soaked in excess solution of $0.5 \mathrm{~N} \mathrm{HCl}$ for 15 minutes as described by (Waltz and Loerch, 1986). Half of the amount was allowed to dry by air at room temperature, and it was named GNCHClA. The other half was dried for 6 hours at $100 \mathrm{C}^{\circ}$ on a forced air oven and was named $\mathrm{GNCHClH}$.

Another $500 \mathrm{gm}$ were sprayed with $50 \%$ water solution of $0.5 \mathrm{~N}$ $\mathrm{HCl}$. Then it was air dried at room temperature, and named GNCHClS. The control was 500 gms of GNC soaked in distilled water for 15 minutes, then it was allowed to dry at room temperature, and named UGNCA.

\section{Animals and feeding:}

Three castrated calves from a local breed (Kenana) aged 2 - 21/2 years, were fitted with rumen cannulae as described by Brown et al. (1968). They were maintained with a well balanced ration of concentrates and roughage. They were fed twice daily.

\section{Ruminal dry matter (DM) and crude protein (CP) degradability study:}

According to the polyester bag technique of Mehrez and Qrskov (1977), the bags were prepared from nylon material of length $15.5 \mathrm{~cm}$, width $8.5 \mathrm{~cm}$ and weighing $2-3 \mathrm{gm}$. The empty bags were individually weighed and their weights recorded. Three gms of treated or untreated cakes were put in a bag tied with a nylon ribbon, attached to a plastic 
tube, of $45.5 \mathrm{~cm}$ length, $0.8 \mathrm{~cm}$ diameter, and introduced inside the rumen. The bags ( 2 bags/animal/period/treatment) were incubated for 6 , 12, 24, 36, 48 and 72 hours each.

\section{Calculation of ruminal degradability:-} formula:

Degraded dry matter percentage was calculated according to the

$\underline{\text { Weight of sample incubated }- \text { Weight of residue after incubation }} \times 100$

Weight of sample incubated

Residual samples after incubation for each period were separately mixed, pooled and made ready for $\mathrm{CP}$ content determination(AOAC, 1980).

Degraded protein was calculated according to the formula:-

$\underline{\mathrm{CP} \text { of sample incubated }-\mathrm{CP} \text { of residue after incubation }} \times 100$

$\mathrm{CP}$ of sample incubated

The degradation kinetics of the incubated cake (treated or untreated) was described by curve-linear regression of DM or CP loss from the bags with time by the equation of Qrskov and McDonald (1979).

$\mathrm{P}=\mathrm{a}+\mathrm{b}\left(1-\exp ^{-\mathrm{ct}}\right)$

Where:

$\mathrm{P}=$ potential degradability (percentage)

$\mathrm{a}=$ the soluble fraction (percentage).

$\mathrm{b}=$ the potentially degradable fraction (percentage).

$\mathrm{c}=$ the rate of degradation of $\mathrm{b}$ (percentage /hour).

$\mathrm{t}=$ time (hour).

Effective degradability (Ed) of DM and CP was determined, at $0.02,0.05$ and 0.08 ruminal outflow rates, using the equation of Orskov and McDonald (1979) stated above.

\section{Statistical analysis:-}

The data obtained were subjected to one way analysis of variance to examine the effect of the treatment on DM and CP degradation kinetics. Significant differences among the treatments were determined using Least Significant Differences (LSD) test according to Gomez and Gomez, (1984). The Statistical Package for Social Sciences Program (SPSS) was used for the analysis.

\section{RESULTS}

The proportion of the dry matter disappearance from the nylon bags at different incubation periods for UGNC and all the forms of $\mathrm{HCl}$ treatments is shown in Table (1). Significant differences $(\mathrm{P}<0.05)$ were 
found between the treated GNC and UGNC as well as among treated cakes at all incubation periods. All treatments decreased $(\mathrm{P}<0.05) \mathrm{DM}$ degradation at all incubation periods except $\mathrm{GNCHCl} \mathrm{S}$ decreased it at $6 \mathrm{hrs}$ and zero time only. Among treatments, GNCHClH had the lowest $(\mathrm{P}<0.05) \mathrm{DM}$ degradation rate at all the incubation periods than the other treatments.

Table (2) shows the dry matter disappearance from a fitted model for different $\mathrm{HCl}$ treatments. There are significant differences between treated GNC and untreated one, as well as among treatments. With the exception of (b) value of the fitted model, all other values of the control group are higher compared to $\mathrm{HCl}$ treated groups. $\mathrm{GNCHClH}$ exhibited the lowest fitted values of DM degradation.

Degraded protein percentage of $\mathrm{GNC}$ due to different $\mathrm{HCl}$ treatments is shown in Table (3). All treatments significantly decreased ( $\mathrm{P}<0.05) \mathrm{CP}$ degradation. It can be seen that GNCHClA and $\mathrm{GNCHClH}$ showed similar effect on in situ GNC crude protein degradability during the first 24 hrs.

Table (4) shows degraded protein from fitted model for UGNC and different $\mathrm{HCl}$ treatments. There are significant $(\mathrm{P}<0.05)$ differences between treated and untreated GNC. All treatments significantly reduced values a, b, Pd and effective degradability at different rumen outflow rates. Within treatments GNCHClS has the lowest effect.

Table 1: The effect of different $\mathrm{HCl}$ treatments on in situ dry matter disappearance $(\%)$ of GNC.

\begin{tabular}{|c|c|c|c|c|c|c|}
\hline Treatment & $\begin{array}{c}\text { Control } \\
\text { Air }\end{array}$ & $\begin{array}{c}\mathrm{HCl} \\
\text { Air }\end{array}$ & $\begin{array}{c}\mathrm{HCl} \\
\text { Spray }\end{array}$ & $\begin{array}{c}\mathrm{HCl} \\
\text { Heat }\end{array}$ & SEM & Significance \\
\hline Time (hours) & \multicolumn{6}{|l}{} \\
\hline 0 & $36.76^{\mathrm{a}}$ & $20.10^{\mathrm{c}}$ & $26.40^{\mathrm{b}}$ & $13.06^{\mathrm{d}}$ & 2.63 & $*$ \\
6 & $83.80^{\mathrm{a}}$ & $72.33^{\mathrm{c}}$ & $76.40^{\mathrm{b}}$ & $43.43^{\mathrm{d}}$ & 4.64 & $*$ \\
12 & $85.93^{\mathrm{a}}$ & $73.63^{\mathrm{d}}$ & $84.93^{\mathrm{a}}$ & $55.03^{\mathrm{c}}$ & 3.78 & $*$ \\
24 & $92.80^{\mathrm{a}}$ & $84.20^{\mathrm{b}}$ & $90.43^{\mathrm{a}}$ & $72.93^{\mathrm{c}}$ & 2.40 & $*$ \\
36 & $93.03^{\mathrm{a}}$ & $87.20^{\mathrm{b}}$ & $93.13^{\mathrm{a}}$ & $74.83^{\mathrm{c}}$ & 2.25 & $*$ \\
48 & $93.96^{\mathrm{a}}$ & $92.50^{\mathrm{a}}$ & $94.43^{\mathrm{a}}$ & $83.76^{\mathrm{b}}$ & 1.33 & $*$ \\
72 & $94.20^{\mathrm{a}}$ & $93.56^{\mathrm{a}}$ & $94.33^{\mathrm{a}}$ & $92.33^{\mathrm{b}}$ & 0.25 & $*$ \\
\hline
\end{tabular}

* : Significant at $(\mathrm{P}<0.05)$

$\mathrm{a}, \mathrm{b}$, : Means within the same raw followed by different superscripts are significantly $(\mathrm{P}<0.05)$ different.

SEM: standard error of the means. 
Table 2: Insitu GNC dry matter rumen degradability characteristics from fitted model of different $\mathrm{HCl}$ treatments.

\begin{tabular}{|c|c|c|c|c|c|c|}
\hline Treatment & $\begin{array}{c}\text { Control } \\
\text { Air }\end{array}$ & $\begin{array}{c}\mathrm{HCl} \\
\text { Air }\end{array}$ & $\begin{array}{c}\mathrm{HCl} \\
\text { Spray }\end{array}$ & $\begin{array}{c}\mathrm{HCl} \\
\text { Heat }\end{array}$ & SEM & Significance \\
\hline Fitted Values & \multicolumn{6}{|l}{} \\
\hline $\mathrm{a}(\%)$ & $36.92^{\mathrm{a}}$ & $21.09^{\mathrm{c}}$ & $26.63^{\mathrm{b}}$ & $15.66^{\mathrm{b}}$ & 2.38 & $*$ \\
$\mathrm{~b}(\%)$ & $55.82^{\mathrm{c}}$ & $67.71^{\mathrm{b}}$ & $66.19^{\mathrm{b}}$ & $72.42^{\mathrm{a}}$ & 1.84 & $*$ \\
$\mathrm{c}(/ \mathrm{h})$ & $0.28^{\mathrm{a}}$ & $0.18^{\mathrm{b}}$ & $0.21^{\mathrm{b}}$ & $0.06^{\mathrm{c}}$ & 0.02 & $*$ \\
$\mathrm{Pd}(\%)$ & $92.74^{\mathrm{a}}$ & $88.80^{\mathrm{b}}$ & $92.82^{\mathrm{a}}$ & $88.08^{\mathrm{b}}$ & 0.75 & $*$ \\
$\operatorname{Ed}_{(0.02)}$ & $88.98^{\mathrm{a}}$ & $82.24^{\mathrm{c}}$ & $87.21^{\mathrm{b}}$ & $71.02^{\mathrm{d}}$ & 2.11 & $*$ \\
$\operatorname{Ed}_{(0.05)}$ & $84.21^{\mathrm{a}}$ & $74.46^{\mathrm{c}}$ & $80.38^{\mathrm{b}}$ & $56.55^{\mathrm{d}}$ & 3.20 & $*$ \\
$\operatorname{Ed}_{(0.08)}$ & $80.26^{\mathrm{a}}$ & $68.44^{\mathrm{c}}$ & $74.93^{\mathrm{b}}$ & $48.08^{\mathrm{d}}$ & 3.68 & $*$ \\
\hline
\end{tabular}

*: significant at $(\mathrm{P}<0.05)$.

$a, b$, : Means within the same raw followed by different superscripts are significantly $(\mathrm{P}<0.05)$ different.

SEM: standard error of the mean.

a: washing loss.

b: degradation of water insoluble.

c: rate constant of $b$ function.

Pd: potential degradability.

Ed: Effective degradability at rumen outflow rate $(0.02,0.05$, and 0.08$)$.

Table 3: Effect of different $\mathrm{HCl}$ treatments on in situ GNC protein degradability $(\%)$.

\begin{tabular}{|c|c|c|c|c|c|c|}
\hline Treatment & $\begin{array}{c}\text { Control } \\
\text { Air }\end{array}$ & $\begin{array}{c}\mathrm{HCl} \\
\text { Air }\end{array}$ & $\begin{array}{c}\mathrm{HCl} \\
\text { Heat }\end{array}$ & $\begin{array}{c}\mathrm{HCl} \\
\text { Spray }\end{array}$ & SEM & Significance \\
\hline Time (hours) & \multicolumn{6}{|l|}{} \\
\hline 0 & $9.57^{\mathrm{a}}$ & $1.54^{\mathrm{c}}$ & $1.78^{\mathrm{c}}$ & $5.89^{\mathrm{b}}$ & 1.00 & $*$ \\
6 & $25.33^{\mathrm{a}}$ & $2.62^{\mathrm{c}}$ & $3.90^{\mathrm{b}, \mathrm{c}}$ & $7.20^{\mathrm{b}}$ & 2.79 & $*$ \\
12 & $32.81^{\mathrm{a}}$ & $19.26^{\mathrm{c}}$ & $19.57^{\mathrm{c}}$ & $23.74^{\mathrm{b}}$ & 1.66 & $*$ \\
24 & $44.77^{\mathrm{a}}$ & $24.53^{\mathrm{c}}$ & $25.40^{\mathrm{c}}$ & $33.00^{\mathrm{b}}$ & 2.45 & $*$ \\
36 & $50.66^{\mathrm{a}}$ & $30.47^{\mathrm{c}}$ & $27.19^{\mathrm{d}}$ & $33.06^{\mathrm{b}}$ & 2.75 & $*$ \\
48 & $51.73^{\mathrm{a}}$ & $32.05^{\mathrm{d}}$ & $33.32^{\mathrm{c}}$ & $34.98^{\mathrm{b}}$ & 2.40 & $*$ \\
72 & $53.42^{\mathrm{a}}$ & $32.43^{\mathrm{c}}$ & $33.96^{\mathrm{b}, \mathrm{c}}$ & $35.49^{\mathrm{b}}$ & 2.57 & $*$ \\
\hline
\end{tabular}

**: Significant at $(\mathrm{P}<0.05)$

a, b, c and d : Means within the same raw followed by different superscripts are significantly $(\mathrm{P}<0.05)$ different.

SEM: standard error of the means. 
Table 4: Effect of different $\mathrm{HCl}$ treatments on insitu GNC protein degradability characteristics.

\begin{tabular}{|c|c|c|c|c|c|c|}
\hline Treatment & $\begin{array}{c}\text { Control } \\
\text { Air }\end{array}$ & $\begin{array}{c}\mathrm{HCl} \\
\text { Air }\end{array}$ & $\begin{array}{c}\mathrm{HCl} \\
\text { Heat }\end{array}$ & $\begin{array}{c}\mathrm{HCl} \\
\text { Spray }\end{array}$ & SEM & $\begin{array}{c}\text { Significance } \\
\text { level }\end{array}$ \\
\hline Fitted Values & \multicolumn{5}{|l}{} \\
\hline $\mathrm{a}(\%)$ & $9.85^{\mathrm{a}}$ & $-0.97^{\mathrm{c}}$ & $0.02^{\mathrm{c}}$ & $3.03^{\mathrm{b}}$ & 1.28 & $*$ \\
$\mathrm{~b}(\%)$ & $44.08^{\mathrm{a}}$ & $35.42^{\mathrm{b}}$ & $35.34^{\mathrm{b}}$ & $33.76^{\mathrm{b}}$ & 1.26 & $*$ \\
$\mathrm{c}(/ \mathrm{h})$ & $0.06^{\mathrm{a}}$ & $0.05^{\mathrm{c}}$ & $0.04^{\mathrm{b}}$ & $0.06^{\mathrm{a}}$ & 0.002 & $*$ \\
Pd (\%) & $53.92^{\mathrm{a}}$ & $34.80^{\mathrm{c}}$ & $35.36^{\mathrm{b}, \mathrm{c}}$ & $36.83^{\mathrm{b}}$ & 2.40 & $*$ \\
Ed $_{(0.02)}$ & $43.69^{\mathrm{a}}$ & $24.78^{\mathrm{c}}$ & $25.13^{\mathrm{c}}$ & $28.86^{\mathrm{b}}$ & 2.32 & $*$ \\
Ed $_{(0.05)}$ & $34.93^{\mathrm{a}}$ & $17.33^{\mathrm{c}}$ & $17.54^{\mathrm{c}}$ & $22.12^{\mathrm{b}}$ & 2.16 & $*$ \\
Ed $_{(0.08)}$ & $29.77^{\mathrm{a}}$ & $13.23^{\mathrm{c}}$ & $13.48^{\mathrm{c}}$ & $18.17^{\mathrm{b}}$ & 2.02 & $*$ \\
\hline
\end{tabular}

*: Significant at $(\mathrm{P}<0.05)$

$\mathrm{a}, \mathrm{b}$, and $\mathrm{c}$ : Means within the same raw followed by different superscripts are significantly $(\mathrm{P}<0.05)$ different.

a: washing loss.

b: degradation of water insoluble.

c: rate constant of $\mathrm{b}$ function.

Pd: Potential degradability.

Ed: Effective degradability at rumen outflow $(0.02,0.05,0.08)$.

SEM: standard error of the means.

\section{DISCUSSION}

Treatment of groundnut cake with $0.5 \mathrm{~N} \mathrm{HCl}$ decreased the rate of ruminal degradation of both dry matter and crude protein in the different incubation periods as well as effective degradability. Similar results were found by Waltz and Loerch, (1986) upon treating soybean meal with propionic acid, $\mathrm{NaOH}$, or $\mathrm{HCl}$ dried with air. Spraying GNC with $0.5 \mathrm{~N} \mathrm{HCl}$ exhibited the lowest protein protection compared with the other treatment procedures. This agrees with the results of Waltz and Loerch (1986), who found that spraying with acetic acid or propionic acid $(2.5$ or $5 \%)$ caused a higher rate of nitrogen disappearance than when soaked in the same chemicals. This may be attributed to a better distribution of the chemicals into the soaked cake rather than the sprayed cake. Results of the current study revealed that combining heat with $\mathrm{HCl}$ produced the best result in reducing ground nut cake DM and $\mathrm{CP}$ degradation in the rumen. This is on line with the findings of many researchers who worked in protecting soybean meal from rumen degradation; best results for alkali and acid treatments were achieved by heating at $100 \mathrm{C}^{\circ}$ Waltz and Loerch (1986), Cleale et al. (1987) applied 
reducing sugars with heat, while, Lynch et al. (1987) found that $70 \%$ ethanol heated at $78 \mathrm{C}^{\circ}$ improved nitrogen utilization more than heating at $23 \mathrm{C}^{\circ}$.

Heat treatment alone was found to be effective in reducing ruminal degradation rate of soybean seeds nitrogen Plegg et al. (1982), alfalfa hay nitrogen Yang et al. (1993), ground nut cake DM Hussein et al. (2005), and of soybean meal proteins Sadeghi et al. (2006). Heat treatment results in denaturation of the protein, and probably transforming it into a more resistant structure.

$\mathrm{HCl}$ treatment probably produces its protective effect through the alteration of the protein structure, according to Lehninger (1976) exposing proteins to extremes in $\mathrm{pH}$ even for short periods of time causes most proteins to undergo denaturation. This is caused by disruption of hydrogen bonding, resulting in an alteration of the tertiary protein structure. A major effect of denaturation is decreased protein solubility in aqueous solutions (Vander Aar et al., 1982).

Sadeghi et al. (2006) determined the type of protein, of untreated or treated soybean, which escaped rumen degradation due to different chemical and physical treatments. In this study due to limited facilities this was not done, we hope that further studies will follow.

\section{ACKNOWLEDGMENT}

This work was kindly financed by the Ministry of Higher Education and Scientific Research- Sudan.

\section{REFERENCES}

AOAC (1980): Association of Official Analytical Chemists, official methods for analysis. $13^{\text {th }}$.ed. Washington.

Brown, G.F.; Armestrong, D.G. and Macrae, J.C. (1968): The establishment in one operation of cannula into rumen and reentrant cannula into the duodenum and ileum of the sheep. Br. Vet. J. 124, 78-81.

Cleale, R.M.; Klopfenstein, T.J.; Britton, R.A.; Satterlee, I.D. and Lowry, S.R. (1987): Induced non-enzymatic browning of soybean meal. Effects of factors controlling non-enzymatic browning on in vitro ammonia release. J. Physiology. 175: 372385

Gomez, K.A. and Gomez, A.A. (1984): Statistical procedure for agricultural research, $2^{\text {nd }}$ ed. Wily and Sons, Inc. 
Hussein, E.I.A.; Steevens, B. and Belyea, R. (2005): Lowering rumen degradability of groundnut cake by heat treatment. Sud. J. Vet. Sci. Anim. Husb. Vol. 44: 1-2.

Lehninger, A.L. (1976): Biochemistry. Worth Publishers Inc., New York.

Lynch, L.G.; Berger, L.L.; Mercher, R.N.; Fahey, C.G. and Baker, C.E. (1987): Effect of heat and alcohol treatments of soybean on nitrogen utilization by sheep. J. Anim. Sci. 65: 235243.

Mehrez, A.Z. and Qrskov, E.R. (1977): A study of the artificial fiber bag technique for determining the digestibility of feeds in the rumen. J. Agric. Sci. 88: 645-650.

$N R C$ (2001): Nutrient requirements of dairy cattle $7^{\text {th }}$ revised edition.

Plegge, S.D.; Berger, L.L. and Fahey, G.C. (1982): Effect of Roasting on utilization of Soybean meal by ruminant. J. Anim. Sci., 55: 395-401.

Qrskov, E.R. and Mc Donald, I. (1979): The estimation of protein degradability in the rumen from incubation measurements weighed according to rate of passage. J. Agric. Sci. Camb 92: 499-503.

Sadeghi, A.A.; Nikkah, A.; Shawrang, P. and Shahrebabak, M.M. (2006): Protein degradation kinetics of untreated and treated soybean meal using SDS-PAGE. Anim. Feed Sci. Tech. 126: 121-133.

Spears, J.W.; Hatfield, E.E. and Clark, J.H. (1980): Influence of formaldehyde treatment of soyabean meal on performance of growing steers and protein availability in the chick. J. Anim. Sci. 50:750.

Vander Aar, L.L.; Berger, G.C. and Fahey, J.R. (1982): The effect of alcohol treatments on solubility and in vitro and insitu digestibility of soybean meal protein. J. Anim. Sci. 55: 11791189.

Waltz, D.M. and Loerch, S.C. (1986): Effect of acid and alkali treatment of soybean meal on nitrogen utilization by ruminants. J. Agric. Sci. 63: 879-887.

Yang, J.H.; Brodenick, G.A. and Koegel, R.G. (1993): Effect of heat treating Alfalfa hay on chemical composition and ruminal invitro protein degradation. J. Dairy Sci. 76: 154-164. 